\title{
A influência portuguesa na construção da justiça no Brasil
}

\section{The evolution of justice in portugal and the influence on the construction of justice in brazil}

\section{Marcelo Santos Baia}

Como citar esse artigo. SANTOS, M. A influência portuguesa na construção da justiça no brasil. Mosaico - Revista Multidisciplinar de Humanidades, Vassouras, v. 12 , n. 2, p. $58-68$, mai./ ago. 2021.

Nota da Editora. Os artigos publicados na Revista Mosaico são de responsabilidade de seus autores. As informações neles contidas, bem como as opiniões emitidas, não representam pontos de vista da Universidade de Vassouras ou de suas Revistas.

\section{Resumo}

O modo de produção, de comércio e o domínio do mais poderoso sobre o mais fraco é uma característica da própria humanidade desde sempre. Ao analisar tais fatores em várias etapas da história da sociedade ocidental é possível estabelecer um espaço tempo que foi retratado por historiadores. Ao trazer tais conceitos para a história do Direito e da Justiça no Brasil e em Portugal e possível estabelecer de forma clara o poder da metrópole sob a colônia e as características feudais presentes nesta relação, mesmo no século XVII. Este artigo tem por objetivo realizar uma abordagem no âmbito do Direito Comparado acerca da evolução da Justiça em Portugal e a sua influência na construção da Justiça no Brasil. Para isso foram estabelecidos como objetivos específicos apresentar um breve histórico acerca da construção da Justiça em Portugal; rever a hierarquia da Justiça adotada no Brasil colônia; e por fim abordar o que mudou após a independência do Brasil tendo como parâmetro a noção de dignidade da pessoa humana e de cidadania relacionada às Leis voltadas para a questão do elemento servil, considerado como o comércio mais lucrativo até 1888. Como metodologia de pesquisa adotou-se a revisão documental de Portugal e do Brasil, e de literatura baseada em livros, dissertações e artigos científicos publicados em revistas científicas e repositórios acadêmicos em língua portuguesa com conteúdo pertinente ao tema abordado.

Palavras-chave: Justiça. História. Direito Comparado. Brasil. Portugal.

\begin{abstract}
The mode of production, of trade and the domination of the most powerful over the weakest has been a feature of humanity itself since forever. By analyzing these factors at various stages in the history of Western society, it is possible to establish a space-time that was portrayed by historians. By bringing such concepts to the history of Law and Justice in Brazil and Portugal, it is possible to clearly establish the power of the metropolis under the colony and the feudal characteristics present in this relationship, even in the 17 th century. This article aims to carry out an approach within the scope of Comparative Law on the evolution of Justice in Portugal and its influence on the construction of Justice in Brazil. To this end, it was established as specific objectives to present a brief history about the construction of Justice in Portugal; review the hierarchy of justice adopted in colonial Brazil; and finally to address what changed after Brazil's independence, taking as a parameter the notion of human dignity and citizenship related to the Laws related to the issue of the servile element, considered as the most profitable trade until 1888. As a research methodology, it adopted -the documentary review of Portugal and Brazil, and literature based on books, dissertations and scientific articles published in scientific journals and academic repositories in Portuguese with content relevant to the topic addressed.
\end{abstract}

Keywords: Justice. Story. Comparative law. Brazil. Portugal

\section{Introdução}

Conhecer o passado e a construção da sociedade portuguesa colabora para o melhor entendimento da Justiça dos países que foram colônias, como o Brasil, inclusive na contemporaneidade. Contudo, à medida que toda a história depende de como a História é retratada e descrita por historiadores, rever os acontecimentos da ótica de vários profissionais, inclusive de outras áreas, traz um esclarecimento do porquê das consequências atualmente.

Além disso, à medida que o Brasil foi a maior colônia de Portugal, ao mesmo tempo em que o país dependeu durante muito tempo do que era gerado na sua colônia, as influências da Metrópole acabaram por influenciar na forma como a Justiça era operada. Tal dependência do que era produzido nas lavouras e extraído das riquezas no Brasil era considerada como uma estratégia para a monarquia portuguesa.

Desse modo, manter o controle da Justiça enquanto colônia teve consequência na forma como os mais ricos e poderosos agiam após a independência do Brasil. Vale destacar que tal independência foi fruto ou consequência de ações externas, demonstrando que a

Afiliação dos autores

Mestrando em Ciências Jurídicas na Universidade Ual (Universidade Autônoma Luís de Camões - Lisboa) Portugal.

*Email de correspondência: marcelo.advogado.rj@gmail.com 
evolução do Direito e da Justiça não partiu de ações da sociedade ou de questões internas para a adequação aos anseios da população, mas consequência do domínio dos países mais ricos.

Este artigo tem por objetivo realizar uma abordagem no âmbito do Direito Comparado acerca da evolução da Justiça em Portugal e a sua influência na construção da justiça no Brasil, apresentando um breve histórico acerca da construção da Justiça em Portugal, revendo a hierarquia da Justiça adotada no Brasil colônia e por fim abordando o que mudou após a independência do Brasil tendo como parâmetro a noção de dignidade da pessoa humana e de cidadania relacionada às Leis voltadas para a questão do elemento servil, considerado como o comércio mais lucrativo até 1888.

Como metodologia de pesquisa adotou-se a revisão documental de Portugal e do Brasil, e de literatura baseada em livros, dissertações e artigos científicos publicados em revistas científicas e repositórios acadêmicos em língua portuguesa com conteúdo pertinente ao tema abordado.

\section{Breve histórico da justiça em Portugal}

A história da Justiça em Portugal transpassa séculos até chegar ao século XXI e isso se deve ao fato de como a História, ou seja, os fatos reais ocorridos no país, foi retratado pelos historiadores. Um exemplo disso está na forma como foi descrito o período de reinado de D. João I, de 1385 a 1433, e D. Manuel, de 1495 a 1521, quase que excluindo o período que compreende os anos de 1521 a 1557, o reinado de D. João III. Em todos os reinados portugueses, o que vigorava no reino era o regime absolutista onde os monarcas eram equiparados a Deus, controlando deste modo todo o destino da nação e daqueles que viviam em suas terras. Tal cenário só veio a mudar séculos depois quando o conceito de Estado passou a vigorar (PERES, 2012, p. 267; SUBTIL, 2016, p. 4).

Neste capítulo será possível rever, em um breve recorte, como era a organização social, política e jurídica no território português, especialmente no final do período do reinado de D. Manuel, seguindo no Reinado de D. João III. Um período que coincide com a descoberta de novas terras e o início de uma mudança no cenário mundial, onde o comércio de cativos africanos se tornará muito mais intenso e motivo para criação de acordos internacionais e leis que afetaram diretamente a colônia. Desta forma é possível colaborar com um melhor entendimento acerca da influência do sistema jurídico português na sua colônia das Américas, o Brasil.

Wolkmer (2003), acredita que muitos historiadores deixam de privilegiar minimamente a atividade humana, como o seu cotidiano, esquecendo-os em prol de uma temática hegemônica. Desse modo a história acaba sendo relativizada, narrando apenas o que se julga importante, deixando de lado outras informações que podem acabar fazendo diferença dentro de um contexto mais amplo.

Nesse primeiro momento não se pode deixar de destacar que a situação caótica do sistema legal português até meados do século XIII, que foi denominado como uma colcha de retalhos por Peres (2012, p. 267-268), é utilizado como um ponto inicial para a mudança no sistema judicial do país. Tratava-se da união de vários sistemas com características distintas sendo aplicadas ao mesmo tempo, causando um conflito de decisões e de privilégios.

O direito vigente na época era constituído pelo Direito Comum dos povos germânicos (Lex Romana Wisigothorum), que englobava tanto o Código Justiniano como o Direito Canônico; privilégios, que consistiam em direitos que os reis asseguravam aos nobres; forais (leis particulares locais) e leis gerais esparsas (PERES, 2012, p. 267).

Além disso, o domínio do Rei sobre as decisões e o destino de toda a população acabava por tomar vários rumos, ficando dependente apenas da vontade de um. Como consequência, à época, havia uma série de lacunas nas leis, além de contradições que eram utilizadas pelos que detinham o poder (PERES, 2012, p. 267-269).

Como resultado dessa situação caótica, que já vinha sendo observada desde o reinado de D. Duarte (1423-1438), foram formulados livros que traziam em detalhes as questões relacionadas ao comportamento dos súditos, bens, jurisdições, privilégios, punições, crimes, legislações especiais, entre outros temas que, compilados, ficaram conhecidos como Ordenações Afonsinas (SILVA, 2000, p. 299).

A publicação das Ordenações Afonsinas se deu em virtude da situação caótica na qual se encontrava o sistema legal de Portugal. Na formação do Estado Português (11401248), a falta de estrutura e consolidação do Estado refletia-se no campo legislativo. As leis formavam uma verdadeira colcha de retalhos. (PERES, 2012, p.267).

À medida que as Ordenações Afonsinas só entraram em vigor em 1480, com o descobrimento das novas terras nas Américas, já no reinado de D. Manuel, todo o sistema político, jurídico e social das novas terras seguiria os mesmos preceitos descritos em seus livros. Dessa forma o rei garantia uma continuidade do seu domínio e a uniformidade, independentemente de haver um oceano os separando (WOLKMER, 2003, p. 297-298; DI PIETRO, 2006, p. 5-6; PERES, 2012, p. 268-269).

Subtil (2016, p. 4), ao enumerar os feitos no período que compreende o reinado de D. João III, posterior a D. Manuel, promoveu algumas mudanças. O 
autor ressalta que as mudanças na organização política do reino, como a reforma das comarcas, tiveram como consequência uma "maior eficiência nas coberturas administrativas e jurisdicionais" (SUBTIL, 2016, p. 4). Além destas, no período destacado, o reino foi capaz de organizar-se de forma mais produtiva e responsável, inclusive chegando ao ápice da formação de seu exército, uma evolução significativa quando observada a sociedade, por exemplo, no período feudal.

[...] na estrutura econômica feudal a propriedade fundiária assume um caráter fragmentário (instrumento de servilismo), porquanto a mesma porção de terra divide-se entre vários proprietários, subordinados uns aos outros (contraprestação) [...] (WOLKMER, 2003, p. 29).

A organização política e judicial em Portugal foi uma solução necessária. Desse modo as decisões judiciais passaram a seguir uma norma única. Sem isso, as decisões eram pautadas em conceitos abstratos, sem uma vinculação consistente (PERES, 2012).

A visão de Subtil (2016, p. 1-2) acerca do cenário português da época que compreende o reinado de D. João III, mostra uma mudança de visão da narração da história. Ao seguir tal metodologia, o autor apresenta as mudanças estruturais ocorridas como consequência dos fatos econômicos e sociais. O resgate da História de Portugal traz um novo cenário que é apresentado, onde a sociedade e as instituições passaram a fazer parte como protagonistas e não mais como simples coadjuvantes (WOLKMER, 2003, p.262-264).

Além disso, vale destacar que a transição ocorrida no sistema social, político e jurídico na Europa está diretamente relacionada aos negócios, ou seja, as transações comerciais, além das mudanças ocorridas na formação social dos países. Tal transição ocorrida entre os séculos XIV e XV, onde o regime feudal ainda estava muito presente nos países europeus, e o século XVIII voltados muito mais para o capitalismo, mostra como a sociedade e a economia foram protagonistas. Ao comandarem os meios de produção, os burgueses influenciaram tal mudança social, especialmente devido as práticas comerciais de grupos mais ricos que passaram a ocorrer graças à influência que tinham junto ao rei e aos demais membros da monarquia (MAGALHÃES, 1995; WOLKMER, 2003).

O período absolutista português, pertencente a este recorte temporal mencionado, ficou marcado pela forma de controle exercida pelo rei em todas as instâncias da sociedade portuguesa. Tal domínio e controle da sociedade também era observado no âmbito do legislativo, do judiciário e do executivo, além da colônia (PERES, 2012, p. 267-269).

Acerca da formação de instituições que representaram grandes mudanças no reino, destaca-se a criação do Tribunal da Inquisição (1536), e da Mesa da Consciência e Ordens (1532), além da reforma ocorrida na Universidade de Coimbra (1537-1544), uma instituição que deu ao reino grandes nomes na área das letras e da administração (SUBTIL, 2016, p. 4-6).

Durante o reinado de D. João III é possível destacar as nomeações de ministros territoriais, provedores e corregedores feitas por outros monarcas, contudo estes não chegaram ao seu numerário. Isso se deu à medida que D. João III chegou a fazer 22 nomeações/ano, o que voltou a cair após a sua saída do trono. Sendo assim, vale destacar o desempenho na administração de seu reinado e as suas consequências (SUBTIL, 2016, p. 4).

As decisões tomadas durante o reinado de D. João III perduraram por aproximadamente dois séculos, o que representou um grande feito para o país. Essas mudanças colaboraram "para apreender um dos sustentáculos da construção do Estado Moderno" (SUBTIL, 2016, p. 6).

Focando no âmbito do funcionamento das instituições jurídicas é possível observar que houve um caminho nos modelos de Estado (MAGALHÃES, 1995; SUBTIL, 2016, p. 10-13).

Vale destacar as observações feitas por José Subtil (2016, p.9-10) acerca da construção da Justiça portuguesa quando este traça uma linha de pensamento acerca da realidade e da criação do que os historiadores entendiam por Estado Moderno. Elencando que estes personagens advindos dos ambientes acadêmicos e culturais eram capazes de influenciar na forma, no quando e no como surgiu o Estado Moderno, assim como na relação conceitual do que vinha a ser o poder na duologia Reinado X Estado, ou seja, em quem detinha o poder.

À medida que há uma descentralização por meio das nomeações ou mais à frente novas formas de fazer política, o poder também acaba se tornando descentralizado e aos poucos sendo conduzido a uma nova realidade social em Portugal (SUBTIL, 2016, p.9$11)$.

Como poderá ser observado no próximo tópicos, este cenário foi bem diferente do ocorrido na América Portuguesa na mesma época. A influência do feudalismo nos primeiros séculos depois do descobrimento e do início da colonização é bem claro. Tal fato demonstra como o Estado português se comportava de modo medieval com a sua colônia, explorando o que poderia lhe trazer riquezas, além de enxergar o território como fonte de tudo o que fosse possível extrair. Ao mesmo tempo, a Coroa fazia da colônia dependente do que pudesse fornecer, especialmente do que fosse manufaturado (WOLKMER, 2003).

\footnotetext{
Nessa perspectiva, o Brasil-Colônia só poderia gerar produtos tropicais que a Metrópole pudesse revender com lucro no mercado europeu; além disso, as outras atividades produtivas deveriam limitar-se de modo a não estabelecer concorrência, devendo a Colônia adquirir tudo o que a Metrópole tivesse condições de vender. Para Portugal, o Brasil deveria servir seus interesses; existia
} 
para ele e em função dele (WOLKMER, 2003, p. 36).

Segundo Magalhães (1995) a independência judicial em Portugal está relacionada à sua independência política de outros países europeus. Além disso, esta mudança surge como consequência e exigência de pressões sociais e políticas. A estas mudanças, associase ao comportamento relacionado às questões das recompensas e das formas de sanção que eram aplicadas a algumas classes por burocratas e magistrados.

Com o tempo, os limites entre o que era privado praticamente desapareceram, passando a uma nova forma baseada na educação do povo, com a sua alfabetização e conscientização do pertencer, de civilização, de vida em sociedade, além da nova visão religiosa (a partir da metade do século XVIII), e com o Direito liberalindividualista, que está diretamente relacionado a uma forma de cultura mais burguesa. Essa mudança na sociedade como um todo teve, consequentemente, reflexos na organização política e administrativa do país (MAGALHÃES, 1995; PERES, 2012; SUBTIL, 2016, p. 9-10).

Importa salientar agora alguns dos principais institutos do Direito liberal-individualista que se desenvolve no contexto da cultura social burguesa e da produção capitalista da riqueza. $O$ primeiro grande instituto da juridicidade moderna é o direito de propriedade, simbolizando uma forma de poder qualificado como absoluto, exclusivo e perpétuo (WOLKMER, 2003, p. 29).

O cenário visto até então não era mais reflexo da sociedade, logo precisou haver mudanças significativas. As obrigações e obediências muito ligadas às questões religiosas (teológicas: salvação, pecados, fé, leis universais) deste sistema de governo não funcionava mais, passando a dar lugar a um regime mais racional, mais material. Os indivíduos deixam de temer um ente superior, passando então a tomar suas próprias decisões, o que também acabou passando por transformações que levaram cerca de meio século para se solidificarem (SUBTIL, 2016, p. 14).

A doutrina clássica do Direito Natural individualista,
"produto do liberal-contratualismo e do racionalismo do
século XVIII, refletiu as condições sociais e econômicas
da burguesia capitalista ascendente. A função ideológica
do jusnaturalismo enquanto proposição defensora de um
ideal eterno e universal nada mais fez do que esconder
seu real: objetivo, ou seja, possibilitar a transposição
para outro tipo de relação política, social e econômica,
sem revelar os verdadeiros atores beneficiados. Os
princípios enunciados por esse jusnaturalismo mostraram-
se extremamente falsos, ao clamarem por uma retórica
formalista da igualdade, da liberdade e da fraternidade
de todos os cidadãos (WOLKMER, 2003, p. 32-33).

Eventos na história de Portugal, como o terremoto de 1755, as invasões francesas, além dos conflitos internos de certa forma colaboraram para moldar o novo
Estado Português. Com o tempo novos organismos administrativos, conselhos e tribunais foram criados para policiar a própria população. Contudo, como poderá ser observado na próxima parte, esta mudança não gerou reflexos significativos e imediatos na colônia (América Portuguesa), onde todas as atenções dos políticos e da justiça estavam constantemente relacionadas com o comércio de cativos e a manutenção da escravidão interesse direto da elite da época e do Reino - um tema que se manteve central na colônia até mesmo depois da sua independência (PERES, 2012, p. 271-277; SUBTIL, 2016, p. 17-19).

Vale destacar a importância e a influência das ações de Napoleão Bonaparte neste período que teve reflexos na hierarquia da Justiça, como será abordado posteriormente. Devido ao fato de que ele buscava fazer da França uma potência mundial, Bonaparte não economizou esforços para alcançar seus objetivos. Por mais que Portugal estivesse voltado para as questões internas, mantendo-se neutro no embate entre Napoleão e outras nações, especialmente a Grã-Bretanha, o país não ficou de fora das suas consequências, tendo que contar com o apoio inglês, especialmente para a retirada da família real do país (BETHEL, 2002, p. 20-22; SCHEDEL, 2010).

Para que conseguisse se manter neutro diante do embate entre a França e a Inglaterra, especialmente, D. João, o Príncipe Regente de Portugal, decidiu transferir a corte para a sua colônia nas Américas. Devido ao retardamento na tomada de decisão, o Príncipe Regente se viu em uma situação que requereu um acordo com os britânicos, inimigos de Napoleão. Contando com a ajuda dos ingleses, depois de ceder às suas exigências relacionadas ao comércio dos negros africanos no Atlântico, a comitiva real comporta de mais de 15 mil pessoas deixou a Europa (SILVA, 2012, p. 22-24).

José Subtil (2016), ao estudar a estrutura administrativa e organizacional de várias localidades no território português, é capaz de traçar um perfil de um país em que a monarquia seguia regras formuladas por ela mesma, para o conceito de Estado regulador que passa a impor consequências, ou seja, onde há um controle comportamental. Elencando outros estudiosos, assim como filósofos, o autor conclui que o sistema acaba, de uma forma ou outra se regenerando após a derrocada de seus conceitos, aprendendo com seus próprios erros e evoluindo, criando o que o autor menciona, "um estado de ordem que se autorregula" (SUBTIL, 2016, p. 19).

\footnotetext{
$\mathrm{Na}$ ordem sócio-econômica capitalista o regime adquire um aspecto unitário e exclusivo, principalmente nos grandes textos burgueses-individualistas, como o Código Civil Francês. Ao romper com o sistema de exploração e privilégios feudais e ao dar destaque à propriedade privada, expressão do domínio absoluto e inviolável, a legislação napoleônica traduziu os interesses individualistas e os avanços revolucionários dos segmentos sociais que
} 
passaram a exercer, hegemonia, livre, agora, de encargos que oneravam a utilização do solo. (WOLKMER, 2003, p. 29).

Há uma constante evolução onde uma interferência externa pode ser capaz de colaborar para que houvesse um salto que levaria ao atual sistema interno português ao fim, mas que também seria responsável por um novo modelo que atenderia melhor os anseios da própria sociedade, que será capaz de distinguir o que é certo, legal e justo, assim como os conceitos inversos. De modo análogo seguirá o sistema jurídico, contudo, observando o fato de que o Direito, diante das evoluções ocorridas no país, passa a ter um caráter "regulador dos comportamentos expectáveis" (SUBTIL, 2016, p. 21), se autorregulando.

\section{Justiça no Brasil colônia}

Após essa abordagem inicial sobre o cenário político, social e jurídico em Portugal é possível dar início a uma explanação acerca da construção da justiça na maior colônia portuguesa (MATTOSO, 2001, p. 176179). É preciso retomar a um tempo onde o processo de escravidão era muito intenso no mundo ocidental, dessa forma é possível observar que o acesso à Justiça e a forma como as leis que seriam aplicadas pelos operadores à época, eram construídas segundo os objetivos dos mais poderosos, especialmente, os objetivos da metrópole. Apesar das mudanças ocorridas na estrutura social do país, como apresentado, estas não foram estendidas em sua essência à colônia, que ainda vivia um cenário similar ao período medieval enquanto na Metrópole o conceito de Estado estava se consolidando (MAGALHÃES, 1995; PENA, 2001).

Como mencionado anteriormente, após a formulação das Ordenações Afonsinas, todas as terras pertencentes à Portugal deveriam seguir tal ordenação, ou seja, a mesma organização política e consequentemente de privilégios, respeitariam as mesmas leis, assim como os crimes receberiam as mesmas punições. Não houve, portanto, uma construção da justiça voltada para a realidade social das colônias, mas uma imposição devido a sua condição de colônia (WOLKMER, 2003, p. 297-298; PERES, 2012, p. 268-269).

Os primeiros traços de administração da justiça aportaram no Brasil com a expedição de Martim Afonso da Silva, por volta de 1530. Em função da necessidade de estabelecer, de uma forma mais concreta, uma colonização permanente e de regular a sociedade, Martin Afonso recebeu instruções, com amplos poderes judiciais, de tomar medidas que garantissem a exploração da terra. (...) Com poder judicial sobre as pessoas, Martim Afonso tinha ordens da Corte para criar cargos judiciais necessários a correta administração da Colônia (BORGES FILHO, 2001, p.135-136).

Devido as particularidades observadas no território da colônia recém descoberta nas Américas, especialmente a sua extensão, foram criadas as Capitanias Hereditárias. A divisão, que concedia a alguns privilegiados o poder de administrar os territórios previamente delimitados ocorreu em 1534, dentro do período regencial de D. João III (1521-1557). Por meio das Cartas de Doação, os denominados Capitães ou donatários (burgueses e nobres indicados pelo Rei), tomariam posse das sesmarias, onde, apesar de poderem ser administradas de forma independente, deveriam seguir as regras impostas rei (DI PIETRO, 2006, p. 6; PERES, 2012, p. 268-270).

A doação de terras, em sistema de Capitanias, a doze fidalgos portugueses, concedia poderes judiciais a seus proprietários, que podiam nomear pessoas (ouvidores) com alçada civil e criminal. Assim, o proprietário da terra tinha o controle total na administração da justiça. O direito colonial, nasce, portanto, vinculado à propriedade privada e com objetivos claros de controle social. [...] faz-se mister ressaltar que a lei portuguesa no Brasil atingia sobretudo os europeus, uma vez que os nativos eram privados de recorrer aos canais normais de justiça. E mesmo entre os europeus radicados no Brasil, a lei fazia distinção entre fidalgos e o populacho. Somente com a chegada de Mem de Sá (1557), é que os assuntos de justiça são ampliados em detrimento dos poderes judiciais dos donatários (BORGES FILHO, 2001, p. 135-136).

Como na colônia recém descoberta não havia qualquer legislação, Portugal impôs àqueles que viviam em seus domínios as mesmas previsões, normas, leis, entre outros tópicos que estivessem descritos nas Ordenações Afonsinas. No Livro I, que especificava os detalhes acerca da administração da justiça do Reino, trazia enunciados acerca dos cargos públicos e as suas respectivas competências. Todas estas determinações foram sendo aplicadas nas capitanias e fiscalizadas pelo reino para garantir que as suas terras, por mais que estivessem sob administração dos Capitães, seguissem as suas normas (PERES, 2012, p. 268).

Nos primeiros séculos após o descobrimento, o Brasil, colonizado sob a inspiração doutrinária do mercantilismo e integrante do Império português, refletiu os interesses econômicos da Metrópole e, em função deles, articulou-se (WOLKMER, 2003, p. 36).

Di Pietro (2006, p. 6) afirma que, respeitando as normas previstas no Livro II das Ordenações Afonsinas, cabia aos donatários "nomear o seu ouvidor, que exercia função administrativa e judiciária. Era a autoridade máxima, abaixo do capitão, assemelhando-se o seu papel ao de Secretário de Estado."

O poder judicial dos ouvidores era constantemente afetado pelo poder administrativo dos donatários. Por este motivo, para que a independência do Poder Judiciário fosse regulamentada, foi publicado o Alvará de 24 de março de 1708, que previa que os juízes da coroa eram os ouvidores das capitanias, e não os 
donatários (PERES, 2012, p. 270).

Abaixo do Ouvidor (Primeira Instância), que julgava qualquer recurso vindo dos que estavam hierarquicamente abaixo, estavam os Corregedores (Indicado pelo Rei) e os Desembargadores (Segunda Instância), seguido pelo Ouvidor de Comarca e os Juízes, sendo estes dois juízes com competências concorrentes e os juízes de Órfãos (WOLKMER, 2003, p. 300-302; DI PIETRO, 2006, p. 6).

O Juiz de Fora, um Bacharel indicado pelo Rei, julgava segundo as leis do Reino nos casos em que as Ordenações Afonsinas ou qualquer alteração vinda de Portugal assim coubesse. Cabia ao Juiz Ordinário ou Da Terra, pessoas eleitas pela população local sem qualificação equivalente a uma formação na Europa como era exigido dos Juízes De Fora, julgar demandas e questões locais, aplicando os denominados forais. Aos Juízes de Órfãos cabia a missão de julgar exclusivamente as causas envolvendo o direito sucessório (WOLKMER, 2003, p. 300-302; DI PIETRO, 2006, p. 6; PERES, 2012, p. 270-272).

Até 1751 havia um conflito de competência relacionado às decisões dos Juízes, contudo esse problema foi solucionado com a criação do instituto da alçada que passou a definir a competência baseada no valor total da causa. Caso coubesse recurso, este seria julgado por um Corregedor (PERES, 2012, p. 273).

Os Desembargadores, que antes precisavam consultar o Rei antes de dar a sua sentença, com o tempo receberam poderes do Rei para atuarem no chamado Desembargo do Paço. Tal mudança concedeu a estes o poder de tomar decisões sem a necessidade de consulta direta com o Rei. Depois dessa mudança na hierarquia e da distribuição de poderes, apenas os casos de grande relevância, os considerados especiais, eram encaminhados a Casa de Suplicação de Lisboa para que o Rei tomasse a decisão final. Essa situação permaneceu até a mudança da Corte em 1808, quando passou a se chamar Casa de Suplicação do Brasil (PERES, 2012, p. 273).

É possível perceber que, pelo menos até a mudança da Corte para a colônia, nos primeiros séculos de colonização houve uma clara dependência jurídica. $\mathrm{O}$ Direito e a Justiça na colônia permaneceram diretamente relacionados à Metrópole, diferenciando, inclusive, os nativos dos portugueses originários (BORGES FILHO, 2001; MATTOSO, 2001).

Atrelado a isso, outro dado que merece uma relevante observação diz respeito ao julgamento de crimes ocorridos na colônia. Os magistrados à época do Brasil colônia não julgavam todos como cidadãos portugueses, mas de acordo com um papel designado por Portugal. Havia uma diferenciação clara entre os sujeitos que era similar à distinção por meio de classes, usada no período feudal, mas também em sociedades em que tal prática visa a retenção de bens e riquezas
(MAGALHÃES, 1995; MATTOSO, 2001).

Mesmo que à essa altura Portugal já tivesse alcançado uma postura de Estado perante os seus cidadãos, na colônia os mais ricos tinham mais direitos e poderes, enquanto os menos favorecidos viviam à margem, como bem descrito em Dotti (1988) onde o autor menciona o teor de uma carta enviada a Duarte Coelho em 1534 corroborando com a pauta.

Ao capitão era dada a faculdade de nomear ouvidor, o qual conhecia das apelações e agravos de toda a capitania e de ações novas até dez léguas de distância, onde se encontrasse. A alçada do ouvidor era de cem mil réis nas causas cíveis, enquanto nas criminais, o capitão e o ouvidor tinham competência para absolver ou para condenar, impondo qualquer pena, inclusive de morte, salvo tratando-se de uma pessoa de mor qualidade, pois nesse caso - excetuados os crimes de heresia, traição, sodomia e moeda falsa - só tinham alçada até dez anos de degredo e cem cruzados de multa (DOTTI, 1988, p. 46).

À medida que o trecho apresentado remete aos escravos e que o próximo tópico fará um paralelo entre as mudanças ocorridas no Brasil após a sua independência, vale retomar às últimas décadas do século XVIII, enquanto na Europa a submissão dos negros africanos aos brancos diminuía, especialmente diante da pressão feita pelos britânicos, abaixo da linha do Equador esse domínio permanecia firme e forte. Ou seja, enquanto os ingleses insistiam que tal comércio, que tinha nas pessoas o seu objeto, a insistência por parte de Portugal pela sua manutenção ia de encontro a tais questões humanitárias que eram tão aclamadas pelos britânicos (MATTOSO, 2001, p.172-179).

Os envolvidos com o tráfico e o comércio só visavam o lucro financeiro advindo da venda, mas também do transporte e do atravessamento dos negros africanos que fossem, porventura, capturados em seus domínios ou reféns daqueles que invadiam as suas terras e os vendiam como troféus (MAGALHÃES, 1995; MATTOSO, 2001).

No começo do século XIX, quando a Grã-Bretanha lançou a sua cruzada contra o comércio transatlântico de escravos, não havia nenhuma nação mais profundamente envolvida na exportação, no transporte e na importação de escravos africanos do que Portugal (BETHEL, 2002, p. 21)

Estas pessoas que eram levadas para a colônia portuguesa em navios negreiros em situações desumanas, passavam vários meses em alto mar sem as mínimas condições de sobrevivência. Elas praticamente não tinham o que comer e nem beber, mas além disso, eram colocados em situações sujeitas a doenças que poderiam matá-los, além do risco de naufrágios (MATTOSO, 2001, p. 177-185). Após essa travessia, os negros desembarcavam no Brasil e eram vendidos como mercadorias. Segundo a visão de Mattoso (2001, p. 165-176), os mais fortes eram vendidos em questão de 
minutos, deixando em segundo plano os mais fracos.

Tal cenário apresentado perdurou por muito tempo e, mesmo diante de várias tentativas dos abolicionistas, os processos para a construção de leis eram lento e não davam um fim definitivo à questão. Isso ocorreu devido ao fato de que os operadores do Direito e os Legisladores da época herdaram uma herança das características portuguesas associadas ainda ao período feudal.

[...] a matriz jurídica trazida e imposta às colônias da América Latina, como o Brasil, advém da implantação e adequação das fontes históricas luso romanísticas, bem como do processo posterior de assimilação do legado institucional e regulador colonialista ibérico, para uma estrutura social dependente e periférica. Particularmente durante o período da colonização portuguesa, prevaleceu a reprodução de um aparato jurídicorepressivo patrimonialista compatível com a organização produtiva escravista, ao passo que, com a Independência do país e o rompimento com a Metrópole, forjaram-se as condições para que uma elite nacional, mantendo o controle sobre a economia de exportação, incorporasse e difundisse os princípios de uma tradição jurídica, formalmente dogmático-positivista e retoricamente liberal-individualista, sem deixar de ser excludente (WOLKMER, 2003, p. 113).

Diante do que foi apresentado é possível traçar uma sequência que mostra a forma como a Justiça no Brasil foi influenciada pelas características de um Portugal mais medieval, como apontado anteriormente. Além disso, que os escravos eram colocados em condição abaixo dos nascidos na colônia, sem qualquer direito ou proteção jurídica.

\begin{abstract}
Não resta dúvida de que o nascedouro da produção jurídica no Brasil está profundamente amarrado a um passado econômico colonial e à implantação de um sistema sóciopolítico discriminador, marcado por uma historicidade 'conciliadora' e por um nível de desenvolvimento nem sempre compatível com as necessidades e exigências do país. Certamente, é na origem mercantilista, absolutista e contra-reformista na formação social portuguesa que se podem buscar, ainda que remontassem os primeiros fatores geradores de uma tradição político-jurídico burocrática, individualista, erudita e legalista (WOLKMER, 2003, p. 114).
\end{abstract}

À medida que a construção da sociedade no Brasil, desde o seu descobrimento e mesmo depois de muito tempo, ainda estava diretamente relacionada às famílias dos portugueses mais poderosos e ricos, seus interesses eram sempre colocados acima dos interesses públicos. Sendo assim, a maioria dos parlamentares envolvidos na construção das leis relacionadas à escravidão, o comércio mais lucrativo por muito tempo, tinham ligação direta com os senhores de escravos e de terras, onde usavam os braços fortes desse povo. A exploração visando o lucro financeiro em prol de grupos específicos e que dominavam o cenário político tinha consequências na Justiça à medida que os operadores deveriam seguir as normas estabelecidas pelos legisladores que estavam em Portugal. Em suma, por mais que houvesse passado um longo período desde o descobrimento, tais ações promovidas por Portugal visando o domínio da colônia ainda pode ser associada ao período das capitanias hereditárias (1534) (PERES, 2012, p. 267-268).

Isso configura, desde o início da colonização, uma combinação estranha e atípica de relações políticoeconômicas marcadas, de um lado, pela passagem de uma situação agrária semifeudal para um modo de produção capitalista (ora mercantil, ora industrial), refletindo, regionalmente, as imposições econômicas das metrópoles centrais; de outro, pela incorporação e adaptação, por parte das instituições políticas, de diretrizes patrimonialistas e burocráticas inerentes ao modelo conservador de organização administrativa portuguesa (WOLKMER, 2003, p.40).

Diante disso, ao contrário do visto na construção da Justiça em Portugal abordada inicialmente por Subtil (2016, p.16-19), em que houve uma evolução diante da própria sociedade da época, no Brasil o cenário foi outro. Isso ocorre devido ao fato de que a colônia teve um "dono", onde a exploração dos bens tinha um destino, uma Metrópole que ditava as regras. Que mesmo diante de pressões externas, aqueles que controlavam a formulação e fiscalização das leis estava comprometido com seus próprios interesses, especialmente os que lhes resultariam em ganho financeiro (WOLKMER, 2003, p. 198).

Peres (2012, p. 267-269) concorda com essa colocação ao afirmar que o sistema judicial no Brasil não teve características de uma transformação que ocorre de forma gradual, mas de uma imposição. Portugal, como metrópole, impôs seu sistema, e o Brasil, como colônia, adotou sem questionamentos.

\section{Justiça no Brasil independente}

Devido à brevidade do presente estudo, o Quadro 1 apresenta um breve recorte acerca das primeiras leis voltadas para a questão servil no Brasil, destacando o teor em que aborda as penas aplicáveis ao comércio ilegal. Tais leis associam a pessoa do negro escravizado a um valor erário, ou seja, como uma mercadoria e não como uma pessoa, cidadão. Tal fato demonstra como a Justiça na colônia estava muito associada ao uso da pessoa (negro africano escravizado) e não a sua condição de pessoa humana, como cidadão (PENA, 2001, p. 268269).

As leis relacionadas à escravidão e ao elemento servil apresentaram entre 1831 e 1888 uma série de benefícios aos senhores de escravos, denominandoos, inclusive, em vários momentos como donos, mantendo os escravos na condição de objeto. Não havia uma punição específica para os senhores que eram os compradores, apenas para os atravessadores (1831). Em um segundo momento (1850), a própria lei concede ao Governo, e consequentemente aos seus representantes, 
Quadro 1. A questão servil nas leis do Brasil Independente.

\begin{tabular}{|c|c|}
\hline Lei & Descrição \\
\hline $\begin{array}{c}\text { Lei de } 07 \text { de novembro de } 1831 \\
\text { Lei Feijó-Barbacena }\end{array}$ & $\begin{array}{l}\text { Declara livres todos os escravos vindos de fora do } \\
\text { Império, e impõe penas aos importadores dos mesmos } \\
\text { escravos. }\end{array}$ \\
\hline $\begin{array}{c}\text { Lei }^{\circ} 581 \text { de } 04 \text { de setembro de } \\
1850 \\
\text { Lei Eusébio de Queiroz }\end{array}$ & $\begin{array}{l}\text { Estabelece medidas para a repressão do tráfico de } \\
\text { africanos no Império. Associa valor erário a pessoa. } \\
\text { Os escravos ficavam à conveniência do Governo, } \\
\text { podendo, inclusive, ter que trabalhar sob a sua tutela. }\end{array}$ \\
\hline $\begin{array}{c}\text { Lei N. }{ }^{\circ} 2.040 \text { de } 28 \text { de setembro } \\
\text { de } 1871 \\
\text { Lei do Ventre Livre }\end{array}$ & $\begin{array}{l}\text { Declara livre os filhos de mulher escrava nascido a } \\
\text { partir da promulgação. Estabelece uma indenização } \\
\text { pecuniária ao dono da mãe escrava. Possui brechas } \\
\text { para que o senhor de escravo possa usufruir dos } \\
\text { serviços do filho da mulher escrava. Apesar da } \\
\text { declaração "livre", a lei ainda estabelece valor } \\
\text { associado a pessoa do negro escravo ou seu filho. }\end{array}$ \\
\hline 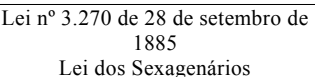 & $\begin{array}{l}\text { Concedeu liberdade aos escravos com } 60 \text { anos de } \\
\text { idade ou mais, cabendo aos donos/proprietários o } \\
\text { pagamento das devidas indenizações. }\end{array}$ \\
\hline $\begin{array}{l}\text { Lei Áurea } \\
1888 .\end{array}$ & $\begin{array}{l}\text { Declarou todos os escravos livres, contudo não deu a } \\
\text { estes uma verdadeira condição de cidadão, com os } \\
\text { mesmos direitos. }\end{array}$ \\
\hline
\end{tabular}

Fonte: Adaptado pelo autor, conforme Brasil $(1831,1850,1871,1888)$.

o usufruto dos escravos.

Após a referida análise e apesar dos benefícios dados aos senhores, a redação das leis passou a apresentar algumas reações dos abolicionistas que reivindicavam uma Justiça mais justa para os escravos e os seus filhos nascidos no Brasil colônia, como a exigência da oficialização da liberdade. Ao mesmo tempo, durante o processo de construção das leis voltadas para a questão servil, os advogados dos senhores de escravos buscavam meios para que tais documentos constassem, de forma Legal, uma série de questões que viessem a favorecer os seus patrões (PENA, 2001; PERES, 2012).

A lei de 1871 é um exemplo claro à medida que declarava a criança nascida livre ao mesmo tempo em que concedia aos donos não apenas uma indenização por parte do Governo pelo nascimento de um filho da sua escrava que não poderia escravizar, mas uma brecha onde proibia a criança de ser afastada da mãe por anos. Dessa forma a criança livre permanecia vivendo nas terras do senhor (COSTA, 2007, p. 70-77).

A Justiça voltada para a questão do elemento servil no Brasil não era a mesma para todas as pessoas. Nas suas redações eram determinadas regras que em um primeiro momento poderia ser benéfica para $o$ escravo, mas após a sua promulgação e usando uma série de questões burocráticas, os donos dos escravos mantinham direitos do usufruto não apenas destes, mas também dos seus filhos, pelo tempo em que estes fossem mais produtivos na lida (PENA, 2001; COSTA, 2007, p.107-108).

Na realidade, os direitos desses novos cidadãos, os alforriados, brasileiros "natos" ou naturalizados, são bem limitados no plano jurídico. Está visto que o forro é reinvestido do direito à família, à propriedade, à herança. É como um menor totalmente emancipado do pátrio poder. Pode até ser escolhido como curador ou tutor de pessoas civilmente incapazes. Mas uma série de restrições priva-no do pleno gozo dos direitos políticos (MATTOSO, 2001, p. 201).
A Justiça à época das leis mencionadas anteriormente não era igualitária, mesmo diante das aparentes evoluções relacionadas à questão servil (COSTA, 2007, p.104-108). Acerca desta distinção, vale destacar os comentários de Campos.

[...] dois códigos foram produzidos, o Criminal e o Processual
Criminal, reservando um tratamento jurídico diretamente
vinculado à figura do escravo. Essa distinção produziu,
inclusive, uma cisão de tratamento penal no Código. Às
pessoaslivres estavareservadootratamentopreconizadopelas
luzes, inspirado no Direito Natural. Aos escravos, mantinha-
se a tradição medieval de suplícios (CAMPOS, 2003, p. 60).

Borges Filho (2001) comenta que no período que compreende as duas primeiras Constituições brasileiras, a sociedade divergia não apenas economicamente, mas também ideologicamente, especialmente os escravocratas e os abolicionistas. A visão de liberdade, de cidadania e também de propriedade no Brasil independente após a virada do século se construiu de forma lenta. Enquanto o branco era considerado realmente como cidadão, o negro, mesmo depois da Lei Áurea, ainda era marginalizado (PENA, 2001; COSTA, 2007, p. 105-108).

\section{[...] se esses indivíduos não eram cidadãos, não gozariam de nenhum direito. As conquistas aconteceriam no cotidiano, nas lutas diárias, negociações num espaço conflituoso. A legislação, não estabelecendo "direitos" aos escravos deixava brechas para interpretações pessoais e contratos sem fins legais (COSTA, 2007, p. 106).}

Vale observar diante do que foi apresentado que, após a declaração de independência, o Brasil passou por um processo de construção do que seria uma nova ordem jurídica, contudo, a influência portuguesa no modus operantes ainda se fez bem presente por algumas décadas. O Judiciário à época da independência, formado especialmente por pessoas letradas em Portugal já que a primeira faculdade de Direito só seria criada em 1827 em Recife e em São Paulo, estruturavam as suas decisões sob influência da metrópole (BORGES FILHO, 2001).

Os vícios crônicos do Reino foram transplantados para a
Colônia como estruturas éticas gravadas nas consciências
dos servidores públicos e dos emigrados, acrescidas,
posteriormente, de antivalores desenvolvidos e a partir
da realidade colonial. Assim, implantou-se uma espécie
de administração calcada nos critérios de pessoalidade,
amizade, parentesco, retribuição, privilégio e em disposições
legais carentes de objetividade, sendo que a ordem pública
que se instituiu veio marcada pelo acaso e pelo arbítrio do
Rei e de seus prepostos (ZANCANARO, 1994, p. 146-147).

Por mais que o Brasil tenha se tornado independente, o seu Poder Judiciário precisou de muitas décadas para abandonar uma influência elitista e patrimonialista portuguesa (BORGES FILHO, 2001; 
PERES, 2012).

Há uma influência clara dos Europeus na construção da Justiça, controlando comportamentos e estabelecendo normas a serem seguidas, além de estabelecer de forma clara a distinção entre os cidadãos e os escravos, por exemplo, como foi possível notar nas leis voltadas para a questão servil (BORGES FILHO, 2001; COSTA, 2007, p. 74-76)

\section{Considerações finais}

Na análise do processo da construção da Justiça no Brasil e em Portugal, questões associadas ao valor da pessoa humana, especialmente quando observado o nascimento e o sobrenome desta, a nacionalidade, assim como a cor da pele, concederam a esta um fator diferencial.

Enquanto Portugal vivia, apesar dos percalços relacionados a guerras e disputas internas e externas, um processo social onde a pessoa passou a decidir o seu destino, no Brasil a influência do Reino ditava as regras sobre as decisões judiciais, e a questão servil era centro de todas as decisões políticas, o que refletia na sociedade e nos processos judiciais.

A influência e o poder em Portugal e no Brasil fazem parte da história da Justiça em ambos os países, contudo, à medida que tais fatores relacionavam-se diretamente a metas distintas, a Justiça se construiu da mesma forma. Não houve, por exemplo, no Brasil, uma busca da classe burguesa pela construção de uma Justiça nacional, mas sim a adequação dos interesses.

O rompimento esperado entre colônia e metrópole após a independência não chegou à ordem sociale de modo análogo à Justiça de modo imediato. Foi necessário um processo de formação mais liberal para que se chegasse a um cenário mais parecido com o dos séculos XX e XXI, fruto de lutas e reivindicações de uma sociedade que se construiu e evoluiu aprendendo com seus próprios erros.

\section{Referências}

BEIGUELMAN, P. Formação política do Brasil. São Paulo: Pioneira, 1976.

BETHEL, L. A Abolição do Comércio Brasileiro de Escravos: a GrãBretanha, o Brasil e a questão do comércio de escravos, 1807-1869 (Luís A. P. Souto Maior, Trad.; Coleção Biblioteca Básica Brasileira). Brasília: Senado Federal, 2002.

BORGES FILHO, N. O Direito da razão ou a razão do direito? Novos Estudos Jurídicos. a. VI, n. 13, 2001, p.131-148. Disponível em: https://siaiap32. univali.br/ seer/index.php/nej/article/view/1490/1185 Acesso em 20 abr 2020

BRASIL. Constituição Política do Império do Brazil de 25 de março de 1824 (1824). Disponível em: http://www.planalto.gov.br/ccivil_03/ constituicao/constituicao24.htm. Acesso em 20 abr 2020.

BRASIL. Lei de 07 de novembro de 1831. Lei Feijó-Barbacena. Disponível em: https://www2.camara.leg.br/legin/fed/lei_sn/1824-1899/lei-37659-7novembro-1831-564776-publicacaooriginal-88704-pl.html. Acesso em 20 abr 2020.

BRASIL. Lei n ${ }^{0} 581$ de 04 de setembro de 1850. Lei Eusébio de Queiroz.
Disponível em: https://www2.camara.leg.br/atividade-legislativa/plenario/ discursos/escrevendohistoria/125-anos-da-lei-aurea/1850-lei-eusebioqueiroz.-o-trafico-negreiro.-historcio-da-lei-581-de-4-de-setembro-de-1850. Acesso em 15 abr 2020.

BRASIL. Lei 3.270 de 28 de setembro de 1885 . Lei dos sexagenários. Disponível em: http://www.planalto.gov.br/ccivil_03/leis/lim/LIM3270. htm\#: :text $=\quad$ Regula $\% 20 \mathrm{a} \% 20$ extinc $\% \mathrm{C} 3 \% \mathrm{~A} 7 \% \mathrm{C} 3 \% \mathrm{~A} 30 \% 20$ gradual $\% 20$ do $\% 20$ elemento $\% 20$ servil.\&text $=$ Art.\&text $=\% \mathrm{C} 2 \% \mathrm{~A} 7 \% 202 \% \mathrm{C} 2 \% \mathrm{BA} \% 20$ A $\% 20$ idade $\% 20$ declarada,matricula $\% 20$ ordenada $\% 20$ por $\% 20$ esta\%20Lei. . Acesso em 09 jun 2021.

BRASIL. Lei N. ${ }^{\circ} \mathbf{2 . 0 4 0}$ de 28 de setembro de 1871. Lei do Ventre Livre. Disponível em: http://www.planalto.gov.br/ccivil_03/leis/lim/lim2040.htm. Acesso em 21 abr 2020.

BRASIL. Lei $\mathbf{n}^{\mathbf{0}} 3.353$ de 13 de maio de 1888. Lei Áurea. Disponível em: http://www.planalto.gov.br/ccivil_03/leis/lim/lim3353.htm\#: :text=LEI\%20 N\%C2\%BA\%203.353\%2C\%20DE\%2013,Art. Acesso em 21 abr. 2020.

CAMPOS, A. P. Nas barras dos tribunais: Direito e escravidão no Espírito Santo do século XIX. Tese (Doutorado em História) - Faculdade de História. Rio de Janeiro: Universidade Federal do Rio de Janeiro, 2003.

COSTA, L. L. ALei do Ventre Livre e os caminhos da liberdade em Pernambuco, 1871-1888. Dissertação (Mestrado em Filosofia) - Faculdade de Filosofia e Ciências Humanas. Recife: Universidade Federal de Pernambuco, 2007.

DI PIETRO, M. S. Z. Direito Administrativo. 19 Ed. São Paulo: Atlas, 2006.

DOTTI, R.A. Bases e alternativas para o sistema de penas. São Paulo: RT, 1988.

MAGALHÃES, P. C. Democratização e independência judicial em Portugal. Análise Social, v. 130, n. 1, 1995, p. 51-90.

MATTOSO, K. de Q. Ser escravo no Brasil. São Paulo: Brasiliense, 2001.

PENA, E. S. Pajens da casa imperial: jurisconsultos, escravidão e a lei de 1871. Campinas: Editora da Unicamp, 2001.

PERES, S. S. Da administração da justiça nas ordenações do reino: evolução e consolidação do poder judiciário brasileiro. Justiça \& História, v. 12, n. 23-24, 2012

RAMOS, C. M. da R. A escravidão, a educação da criança negra e a lei do Ventre Livre (1871): a pedagogia da escravidão. Dissertação (Mestrado em Educação) - Faculdade de Educação. Campinas: Universidade Estadual de Campinas, 2008

SCHEDEL, M. S. F. Guerra na Europa e interesses de Portugal: as colônias e o comércio ultramarino: a acção política e diplomática de D. João de Melo e Castro, V. Conde das Galveias (1792 - 1814). Dissertação (Mestrado). Lisboa: Universidade de Lisboa, 2010.

SILVA, N. J. Espinosa da. História do Direito Português: fontes de direito. $3^{\mathrm{a}}$ ed. Lisboa: Fundação Calouste Gulbenkian, 2000.

SILVA, C. B. Uma perspectiva atlântica: a circulação de mercadorias no Rio de Janeiro após a transferência da Corte portuguesa para o Brasil (1808-1821). Navigator, v. 8, n. 16, 2012, pp. 21-34.

SUBTIL, José. A justiça autopoiética e os municípios portugueses (Séculos XVII e XVIII). e-SLegal History Review ISSN: 1699-5317, núm. 22, Enero, 2016.

WOLKMER, A. C. História do Direito no Brasil. 3. ed. Revista e Atualizada. Rio de Janeiro: Forense, 2003.

ZANCANARO, A. F. A corrupção político-administrativa no Brasil. São Paulo: Acadêmica, 1994 


$$
\text { f }
$$

